\title{
Pengaruh Pupuk Organik dan Anorganik terhadap Pertumbuhan dan Hasil Tanaman Sawi Hijau (Brassica rapa. L)
}

\author{
ARJUNA YOHANNES SIMANULLANG*), NI LUH KARTINI, DAN \\ ANAK AGUNG ISTRI KESUMADEWI
}

Program Studi Magister Lahan Kering, Fakultas Pertanian, Universitas Udayana

${ }^{*}$ E-mail: arjunamanulang06@gmail.com

\begin{abstract}
The Effect of Organic and Inorganic Fertilizers on The Growth and Results of Green Mustard (Brassica rapa L.). Green mustard (Brassica rapa L.) is a vegetable that preferred by many consumers, this causes many farmers cultivate this vegetables. One of the important factor in the cultivation of green mustard is fertilizer type. Alternative to improve soil quality and fertility is by providing organic matter. A field research was conducted to evaluate the effect of organic and inorganic fertilizers on the growth and yield of green mustard, in Banjar Taman Tande, Baturiti Village, Bedugul from April to June 2018. This study was designed with a Randomized Block Design with nested patterns consisting of two factors. The first factor was the type of fertilizer, which was consisted of four types of organic fertilizer, namely: vermicompost, cow manure, chicken manure, goat manure and inorganic fertilizers (NPK Mutiara). The second factor was fertilizer dosage, which was consisted of three levels, namely: 0 tons/ha, 15 tons/ha, and 30 tons/ha, while for NPK Mutiara fertilizer dosages, namely: $0 \mathrm{~kg} / \mathrm{ha}, 150 \mathrm{~kg} / \mathrm{ha}$, and $300 \mathrm{~kg} / \mathrm{ha}$. The results showed that the effect of organic and inorganic fertilizers were not significantly different on the growth and yield of green mustard plants and RAE values. The total $\mathrm{N}$ content of soil on vermicompost treatment was $0.23 \%$ equal to NPK Mutiara. The total population of soil microbes on vermicompost treatment under dosage of 15 tons/ha and 30 tons/ha were $1.4 \times 10^{6} \mathrm{cfu} / \mathrm{g}$ that was much higher compared to NPK Mutiara $150 \mathrm{~kg} / \mathrm{ha}$ fertilizer $\left(0.3 \times 10^{6} \mathrm{cfu} / \mathrm{g}\right)$.
\end{abstract}

Keywords: green mustard, organic fertilizer, anorganic fertilizer.

\section{PENDAHULUAN}

Sawi hijau (Brassica rapa. L) adalah sayuran yang banyak diminati oleh konsumen sehingga banyak yang dibudidayakan karena bernilai ekonomi tinggi, bisa dibudidayakan diberbagai tempat dataran tinggi maupun dataran rendah serta mengandung banyak vitamin. Kandungan vitamin sawi hijau yaitu protein $1,7 \mathrm{~g}$, lemak 0,4 g, karbohidrat 3,4 g, kalsium $123 \mathrm{mg}$, fosfor $40 \mathrm{mg}$, zat besi 1,9 $\mathrm{mg}$ (Zatnika, 2010). Sawi hijau dibudidayakan secara 
ARJUNA YOHANNES SIMANULLANG. et al. Pengaruh Pupuk Organik dan Anorganik...

intensif dengan menggunakan sistem secara konvensional. Prabowo (2008) menyatakan bahwa sistem pertanian yang mengutamakan pemakaian pupuk kimia masih sangat melekat pada model pertanian di Indonesia. Pupuk yang sering digunakan oleh petani umumnya adalah pupuk kimia seperti NPK atau urea, namun pupuk organik juga masih digunakan oleh petani dengan takaran penggunaan yang relatif kecil karena bahannya mudah didapat seperti pupuk kandang sapi, pupuk kandang ayam. Aspek ekologi dari penggunaan pupuk anorganik secara terus menerus dikhawatirkan berdampak buruk bagi lingkungan dan kualitas tanah.

Pupuk organik berasal dari sisa-sisa tanaman, hewan atau manusia, seperti pupuk kandang, pupuk hijau, dan kompos berbentuk cair maupun padat. Jenis pupuk organik yang umum adalah pupuk kambing, pupuk kompos sapi, pupuk kotoran ayam, pupuk kascing. Suparhun et al. (2015) menyatakan bahwa pemberian kotoran kambing dengandosis 30 ton/ha memberikan pengaruh terbaik terhadap pertumbuhan dan produksi tanaman sawi hijau dengan produksi sebesar 24,11 ton/ha. Adriani dan Syahfari (2017) menyatakan bahwa pemberian kompos sapi dengan dosis 15 ton/ha memberikan pengaruh terbaik terhadap pertumbuhan dan produksi tanaman sawi hijau sebesar 28,72 ton/ha. Cindra et al. (2005) menyatakan bahwa pemberian kotoran ayam dengan dosis 20 ton/ha memberikan pengaruh terbaik terhadap pertumbuhan dan produksi tanaman sawi hijau dengan produksi sebesar 215 g/tanaman. Artha et al. (2018) menyatakan bahwa penggunaan kompos kascing pada tanaman sawi hijau dengan dosis 26 ton/ha menunjukkan pertumbuhan dan hasil yang terbaik dengan produksi sebesar 25,28 ton/ha. Kholidin (2015) menyatakan bahwa dosis pupuk NPK 200 kg/ha menunjukkan pertumbuhan dan hasil yang terbaik pada sawi hijau dengan produksi sebesar 294,97 g/tanaman.

Pada penelitian ini pupuk organik diaplikasikan ke media tanam di setiap perlakuan dengan dosis yang berbeda untuk melihat nilai $R A E$ yaitu dosis mana yang memberi pengaruh terbaik pada pertumbuhan dan hasil tanaman sawi hijau serta mengetahui jumlah total mikroba pada masing-masing pupuk perlakuan. Penelitian ini juga membandingkan antara pupuk organik dengan pupuk anorganik rekomendasi sehingga terdapat juga perlakuan yang menggunakan pupuk anorganik dengan dosis yang telah dianjurkan. 
Berdasarkan latar belakang tersebut, maka dilakukan penelitian tentang pengaruh pupuk organik dan anorganik terhadap pertumbuhan dan hasil tanaman sawi hijau (Brassica rapa. L).

\section{BAHAN DAN METODE}

Penelitian dilakukan di lahan kebun milik petani sayuran organik yang bekerja sama dengan yayasan BOA yaitu Bapak Balik, beralamat di Banjar Taman Tande Desa Baturiti, Bedugul dengan ketinggian tempat $1240 \mathrm{~m}$ dpl. Penelitian dilakukan selama 2 bulan. Analisis tanah dilakukan sebelum percobaan. Percobaan dilakukan dari bulan April s/d Juni 2018 selama 60 hari.

Bahan-bahan yang digunakan dalam penelitian ini adalah benih sawi hijau varietas caisim. Pupuk yang digunakan adalah, pupuk kascing, pupuk kandang sapi, pupuk kandang ayam, pupuk kandang kambing, dan NPK Mutiara. Alat yang digunakan adalah alatalat umum yang digunakan untuk pengolahan lahan, cangkul, rol meter, pisau, ember, gembor, hand sprayer, oven, timbangan analitik, pH meter, alat tulis menulis, media Nutrient Agar (NA), media PDA (Potato Dextrose Agar), dan kamera digital.

Percobaan ini didesain dengan Rancangan Acak Kelompok (RAK) pola tersarang yang terdiri atas dua faktor. Faktor pertama adalah jenis pupuk, yang terdiri atas lima jenis, yakni :

$$
\begin{aligned}
& \mathrm{A}=\text { Pupuk kascing } \\
& \mathrm{B}=\text { Pupuk kandang sapi } \\
& \mathrm{C}=\text { Pupuk kandang kambing } \\
& \mathrm{D}=\text { Pupuk kandang ayam } \\
& \mathrm{E}=\text { Pupuk NPK mutiara }
\end{aligned}
$$

Faktor kedua adalah dosis pupuk, yang terdiri atas tiga taraf yakni :

Pupuk kascing, terdiri atas tiga taraf yaitu

$1=0$ ton/ha, $(\mathrm{A} 0)$

$2=15$ ton/ha, (A1)

$3=30$ ton/ha, (A2)

Pupuk kandang sapi, terdiri atas tiga taraf yaitu :

$1=0$ ton/ha, $(\mathrm{B} 0)$

$2=15$ ton/ha, (B1)

$3=30$ ton/ha, (B2)

Pupuk kandang kambing, terdiri atas tiga taraf yaitu :

$1=0$ ton/ha, $(\mathrm{C} 0)$

$2=15$ ton/ha, $(\mathrm{C} 1)$

$3=30$ ton/ha, $(\mathrm{C} 2)$

Pupuk kandang ayam, terdiri atas tiga taraf yaitu:

$1=0$ ton/ha, (D0)

$2=15$ ton/ha, (D1)

$3=30$ ton/ha, (D2) 
ARJUNA YOHANNES SIMANULLANG. et al. Pengaruh Pupuk Organik dan Anorganik...

Pupuk NPK mutiara, terdiri atas tiga taraf yaitu :

$$
\begin{aligned}
& 1=0 \mathrm{~kg} / \mathrm{ha},(\mathrm{E} 0) \\
& 2=150 \mathrm{~kg} / \mathrm{ha},(\mathrm{E} 1) \\
& 3=300 \mathrm{~kg} / \mathrm{ha},(\mathrm{E} 2)
\end{aligned}
$$

Tanah diolah sebanyak 2 kali dengan cangkul kemudian diratakan lalu dibuat guludan setinggi $5 \mathrm{~cm}$ dan diberi mulsa pada bedengan, selanjutnya dibuat petak dengan ukuran $100 \mathrm{~cm} \quad$ x $20 \mathrm{~cm}$. Jarak antar perlakuan $20 \mathrm{~cm}$, sedangkan jarak antar ulangan $50 \mathrm{~cm}$. Pengolahan tanah dilakukan dengan penggemburan dan pembuatan bedengan. Tahap penggemburan yaitu pencangkulan untuk memperbaiki struktur tanah dan sirkulasi udara. Tanah yang digemburkan, dibersihkan dari rerumputan, semak atau gulma yang tumbuh.

Penanaman dilakukan dengan terlebih dahulu menumbuhkan benih pada media tray, lalu setelah benih tumbuh dipindahkan ke dalam bedengan dan setiap lubang ditanam dua batang tanaman sawi. Pemeliharaan tanaman meliputi penyiraman yang dilakukan dua kali sehari, yaitu pada pagi dan sore hari dengan air tanah menggunakan selang.

Pemanenan dilakukan setelah 35 HST dan waktu panen pada pagi hari, hal ini dilakukan agar tanaman sawi hijau masih dalam keadaan segar. Panen dilakukan dengan cara mencabut seluruh tanaman setelah itu dipisahkan dengan akarnya lalu ditimbang.

Data Variabel yang diamati meliputi: (1) pertumbuhan dan hasil tanaman sawi hijau, serta (2) efisiensi agronomi pupuk (3) sifat kimia tanah yaitu kadar N, dan P tanah, (4) sifat umum biologi tanah yaitu : jumlah total mikroba, jumlah total jamur, dan respirasi tanah masing-masing sebanyak 15 sampel.

Data hasil pengamatan pada parameter pertumbuhan dan hasil disajikan dalam bentuk tabel yang menunjukkan berbagai perlakuan dan ulangan. Selanjutnya dianalisis menggunakan analisis varian (sidik ragam) dengan program Costat. Apabila perlakuan berbeda nyata dilanjutkan dengan uji Duncan's pada taraf $5 \%$.

\section{HASIL DAN PEMBAHASAN}

Berdasarkan hasil analisis tanah awal dapat dilihat pada Tabel 1. Analisis statistika signifikansi pengaruh pupuk organik dan anorganik terhadap pertumbuhan dan hasil tanaman sawi hijau terhadap variabel yang diamati seperti pada Tabel 2. Pupuk organik dan anorganik menunjukkan pengaruh yang tidak nyata terhadap variabel pengamatan pertumbuhan dan hasil tanaman sawi hijau (Brassica rapa L.). 
Tabel 1. Analisis tanah awal sebelum penelitian

\begin{tabular}{ccccc}
\hline No & Jenis Analisis & Nilai & Kriteria & Metode \\
\hline 1 & pH tanah & 6,65 & Netral & pH H $\mathrm{H}_{2} \mathrm{O} 1: 2,5$ \\
2 & N-total (\%) & 0,185 & Rendah & Kjedhal's \\
3 & P-tersedia (mg kg-1) & 176,153 & Sangat Tinggi & Bray-1 \\
4 & K-tersedia (mg kg-1) & 0,541 & Tinggi & Bray-1 \\
5 & C-organik (\%) & 2,423 & Sedang & Walkley and Black \\
6 & Daya Hantar Listrik (DHL) & 0,310 & Rendah & Konduktimeter \\
7 & Populasi Mikoorganisme (spk) & $51 \times 10^{6}$ & Tinggi & Hitungan Cawan \\
8 & KU & 20,215 & Tinggi & Garvimetri \\
\hline \multicolumn{5}{r}{ Keterangan : Analisis ini dilakukan di Laboratorium Ilmu Tanah dan Lingkungan Fakultas } \\
\multicolumn{4}{c}{ Pertanian Universitas Udayana Denpasar. }
\end{tabular}

Tabel 2. Signifikansi Pengaruh Pupuk Organik terhadap Pertumbuhan dan Hasil Tanaman Sawi Hijau (Brassica rapa L.) umur 35 hst.

\begin{tabular}{|c|c|c|c|c|c|c|}
\hline \multirow{2}{*}{ No } & \multirow{2}{*}{ Variabel } & \multicolumn{5}{|c|}{ Pengaruh Perlakuan } \\
\hline & & $\mathrm{A}$ & $\mathrm{B}$ & $\mathrm{C}$ & $\mathrm{D}$ & $E$ \\
\hline 1. & Tinggi Tanaman & ns & $\mathrm{ns}$ & ns & $\mathrm{ns}$ & ns \\
\hline 2. & Jumlah Daun & ns & ns & ns & ns & ns \\
\hline 3. & Panjang daun & ns & ns & ns & $\mathrm{ns}$ & ns \\
\hline 4. & Lebar daun & ns & ns & ns & ns & ns \\
\hline 5. & Berat Segar Tanaman & ns & ns & ns & ns & ns \\
\hline 6 & Berat Kering Tanaman & ns & ns & ns & ns & ns \\
\hline 7 & Berat Segar Akar & $\mathrm{ns}$ & ns & ns & ns & ns \\
\hline 8 & Berat Kering akar & ns & ns & ns & ns & ns \\
\hline
\end{tabular}

Keterangan : ns : Berpengaruh tidak nyata $(\mathrm{P} \geq 0,05)$ 
ARJUNA YOHANNES SIMANULLANG. et al. Pengaruh Pupuk Organik dan Anorganik...

Tabel 3. Pengaruh Pupuk Organik dan Anorganik terhadap Nilai rata-rata Tinggi Tanaman Sawi Hijau (Brassica rapa L.) (cm) Umur 35 hst.

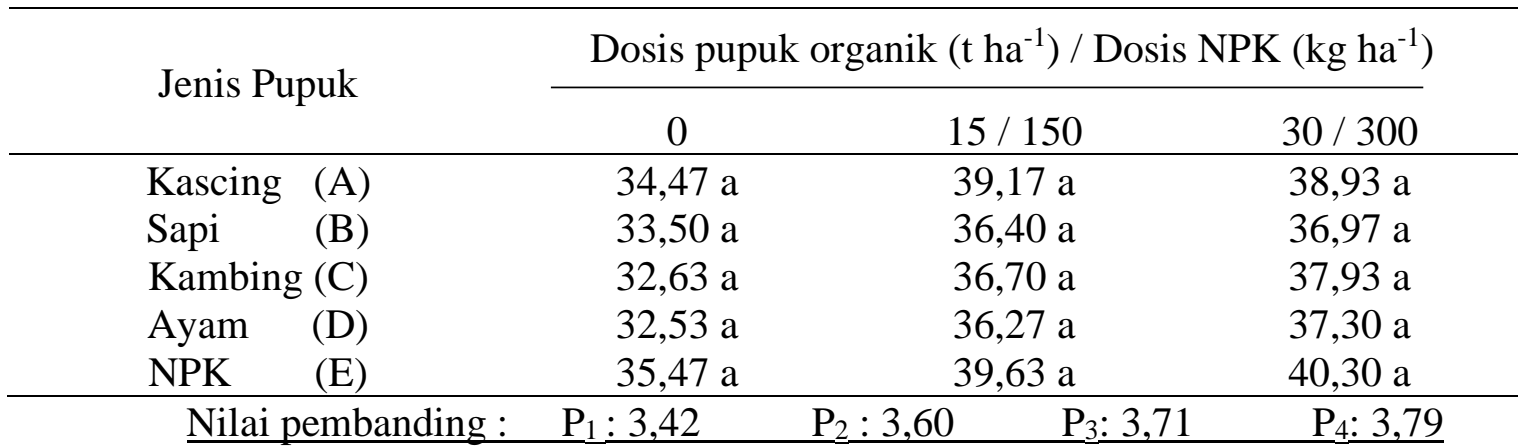

Keterangan : angka-angka yang diikuti oleh huruf yang sama pada kolom berarti berbeda tidak nyata berdasarkan pada uji Duncan $5 \%$.

Tabel 4. Pengaruh Pupuk Organik dan Anorganik terhadap Nilai rata-rata Jumlah Daun Tanaman Sawi Hijau (Brassica rapa L.) (helai) Umur 35 hst.

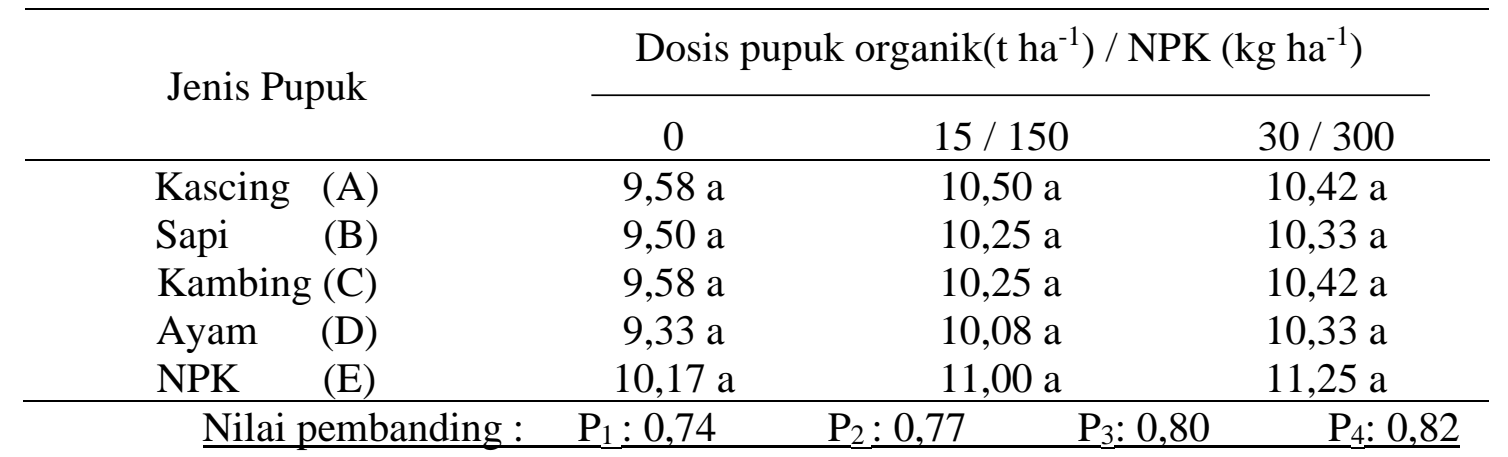

Keterangan : angka-angka yang diikuti oleh huruf yang sama pada kolom yang sama berarti berbeda tidak nyata berdasarkan pada uji Duncan $5 \%$.

Tabel 5. Pengaruh Pupuk Organik dan Anorganik terhadap Nilai rata-rata Panjang Daun Tanaman Sawi Hijau (Brassica rapa L.) (cm) Umur 35 hst.

\begin{tabular}{|c|c|c|c|}
\hline \multirow{2}{*}{ Jenis Pupuk } & \multicolumn{3}{|c|}{ Dosis pupuk organik $\left(\mathrm{t} \mathrm{ha}^{-1}\right) /$ Dosis NPK $\left(\mathrm{kg} \mathrm{ha}^{-1}\right)$} \\
\hline & 0 & $15 / 150$ & $30 / 300$ \\
\hline Kascing (A) & $16,38 \mathrm{a}$ & $17,53 \mathrm{a}$ & $17,13 \mathrm{a}$ \\
\hline Sapi $\quad$ (B) & $16,43 \mathrm{a}$ & $17,47 \mathrm{a}$ & $17,10 \mathrm{a}$ \\
\hline Kambing (C) & $16,47 \mathrm{a}$ & $17,42 \mathrm{a}$ & $17,39 \mathrm{a}$ \\
\hline Ayam (D) & $16,26 \mathrm{a}$ & $17,19 \mathrm{a}$ & $17,20 \mathrm{a}$ \\
\hline NPK $\quad(E)$ & $16,68 \mathrm{a}$ & $18,52 \mathrm{a}$ & $18,68 \mathrm{a}$ \\
\hline \multicolumn{2}{|c|}{ Nilai pembanding: } & $\mathrm{P}_{2}: 0,77$ & $\mathrm{P}_{4}: 0$ \\
\hline
\end{tabular}

Keterangan : angka-angka yang diikuti oleh huruf yang sama pada kolom yang sama berarti berbeda tidak nyata berdasarkan pada uji Duncan $5 \%$. 
Tabel 6. Pengaruh Pupuk Organik dan Anorganik terhadap Nilai rata-rata Lebar Daun Tanaman Sawi Hijau (Brassica rapa L.) (cm) Umur 35 hst.

\begin{tabular}{|c|c|c|c|}
\hline \multirow{2}{*}{ Jenis Pupuk } & \multicolumn{3}{|c|}{ Dosis pupuk organik $\left(\mathrm{t} \mathrm{ha}^{-1}\right) /$ Dosis NPK $\left(\mathrm{kg} \mathrm{ha}^{-1}\right)$} \\
\hline & 0 & $15 / 150$ & $30 / 300$ \\
\hline Kascing (A) & $7,09 \mathrm{a}$ & $7,52 \mathrm{a}$ & $7,21 \mathrm{a}$ \\
\hline Sapi (B) & $6,70 \mathrm{a}$ & $7,40 \mathrm{a}$ & $7,38 \mathrm{a}$ \\
\hline Kambing (C) & $6,93 \mathrm{a}$ & $7,49 \mathrm{a}$ & $7,37 \mathrm{a}$ \\
\hline Ayam (D) & $6,45 \mathrm{a}$ & $7,04 \mathrm{a}$ & $7,22 \mathrm{a}$ \\
\hline NPK $\quad(E)$ & $7,45 \mathrm{a}$ & $7,64 \mathrm{a}$ & $7,67 \mathrm{a}$ \\
\hline \multicolumn{2}{|l|}{ Nilai pembanding: } & $\mathrm{P}_{3}: 0,55$ & $\mathrm{P}_{4}: 0,56$ \\
\hline
\end{tabular}

Keterangan : angka-angka yang diikuti oleh huruf yang sama pada kolom yang sama berarti berbeda tidak nyata berdasarkan pada uji Duncan $5 \%$.

Tabel 7. Pengaruh Pupuk Organik dan Anorganik terhadap Nilai rata-rata Berat Segar Tanaman Sawi Hijau (Brassica rapa L.) (g) Umur 35 hst.

\begin{tabular}{llccc}
\hline \multirow{2}{*}{ Jenis Pupuk } & \multicolumn{3}{c}{ Dosis pupuk organik $\left(\mathrm{t} \mathrm{ha}^{-1}\right) /$ Dosis NPK $_{\left(\mathrm{kg} \mathrm{ha}^{-1}\right)}$} \\
\cline { 3 - 5 } \multicolumn{2}{l}{ Kascing (A) } & 0 & $15 / 150$ & $30 / 300$ \\
\hline Sapi & (B) & $299,74 \mathrm{a}$ & $326,98 \mathrm{a}$ & $325,82 \mathrm{a}$ \\
Kambing (C) & $295,98 \mathrm{a}$ & $309,06 \mathrm{a}$ & $319,81 \mathrm{a}$ \\
Ayam & (D) & $298,01 \mathrm{a}$ & $316,59 \mathrm{a}$ & $323,93 \mathrm{a}$ \\
NPK & (E) & $294,40 \mathrm{a}$ & $316,29 \mathrm{a}$ & $317,57 \mathrm{a}$ \\
\hline
\end{tabular}

Nilai pembanding: $\quad \mathrm{P}_{1}: 76,28 \quad \mathrm{P}_{2}: 80,15 \quad \mathrm{P}_{3}: 82,66 \quad \mathrm{P}_{4}: 84,42$

Keterangan : angka-angka yang diikuti oleh huruf yang sama pada kolom yang sama berarti berbeda tidak nyata berdasarkan pada uji Duncan $5 \%$

Tabel 8. Pengaruh Pupuk Organik dan Anorganik terhadap Nilai rata-rata Berat Kering Tanaman Sawi Hijau (Brassica rapa L.) (g) Umur 35 hst

\begin{tabular}{llccc}
\hline \multirow{2}{*}{ Jenis Pupuk } & \multicolumn{3}{c}{ Dosis pupuk organik $\left(\mathrm{t} \mathrm{ha}^{-1}\right) /$ Dosis NPK $\left(\mathrm{kg} \mathrm{ha}^{-1}\right)$} \\
\cline { 2 - 5 } & \multicolumn{3}{c}{$15 / 150$} & $30 / 300$ \\
\hline Kascing (A) & $24,11 \mathrm{a}$ & $25,96 \mathrm{a}$ & $25,83 \mathrm{a}$ \\
Sapi & (B) & $23,80 \mathrm{a}$ & $25,38 \mathrm{a}$ & $25,31 \mathrm{a}$ \\
Kambing (C) & $23,55 \mathrm{a}$ & $25,52 \mathrm{a}$ & $25,54 \mathrm{a}$ \\
Ayam & (D) & $23,68 \mathrm{a}$ & $25,45 \mathrm{a}$ & $25,33 \mathrm{a}$ \\
NPK & (E) & $24,74 \mathrm{a}$ & $26,50 \mathrm{a}$ & $26,55 \mathrm{a}$ \\
\hline
\end{tabular}

Nilai pembanding: $\quad \mathrm{P}_{1}: 1,31 \quad \mathrm{P}_{2}: 1,38 \quad \mathrm{P}_{3}: 1,43 \mathrm{P}_{4}: 1,46$

Keterangan : angka-angka yang diikuti oleh huruf yang sama pada kolom yang sama berarti berbeda tidak nyata berdasarkan pada uji Duncan $5 \%$ 
ARJUNA YOHANNES SIMANULLANG. et al. Pengaruh Pupuk Organik dan Anorganik...

Tabel 9. Pengaruh Pupuk Organik dan Anorganik terhadap Nilai rata-rata Berat Segar Akar Tanaman Sawi Hijau (Brassica rapa L.) (g) Umur 35 hst.

\begin{tabular}{llccc}
\hline \multirow{2}{*}{ Jenis Pupuk } & \multicolumn{3}{c}{ Dosis pupuk organik $\left(\mathrm{t} \mathrm{ha}^{-1}\right) /$ Dosis NPK $\left(\mathrm{kg} \mathrm{ha}^{-1}\right)$} \\
\cline { 3 - 5 } \multicolumn{2}{l}{} & 0 & $15 / 150$ & $30 / 300$ \\
\hline Kascing & (A) & $10,58 \mathrm{a}$ & $12,41 \mathrm{a}$ & $12,24 \mathrm{a}$ \\
Sapi & (B) & $9,93 \mathrm{a}$ & $11,34 \mathrm{a}$ & $12,06 \mathrm{a}$ \\
Kambing (C) & $9,91 \mathrm{a}$ & $11,73 \mathrm{a}$ & $12,19 \mathrm{a}$ \\
Ayam & (D) & $8,35 \mathrm{a}$ & $11,69 \mathrm{a}$ & $11,55 \mathrm{a}$ \\
NPK & (E) & $8,98 \mathrm{a}$ & $12,64 \mathrm{a}$ & $12,66 \mathrm{a}$ \\
\hline
\end{tabular}

Nilai pembanding: $\quad \mathrm{P}_{1}: 1,48 \quad \mathrm{P}_{2}: 1,56 \quad \mathrm{P}_{3}: 1,61 \quad \mathrm{P}_{4}: 1,64$

Keterangan : angka-angka yang diikuti oleh huruf yang sama pada kolom yang sama berarti berbeda tidak nyata berdasarkan pada uji Duncan $5 \%$

Tabel 10. Pengaruh Pupuk Organik dan Anorganik terhadap Nilai rata-rata Berat Kering Akar Tanaman Sawi Hijau (Brassica rapa L.) (g) Umur 35 hst.

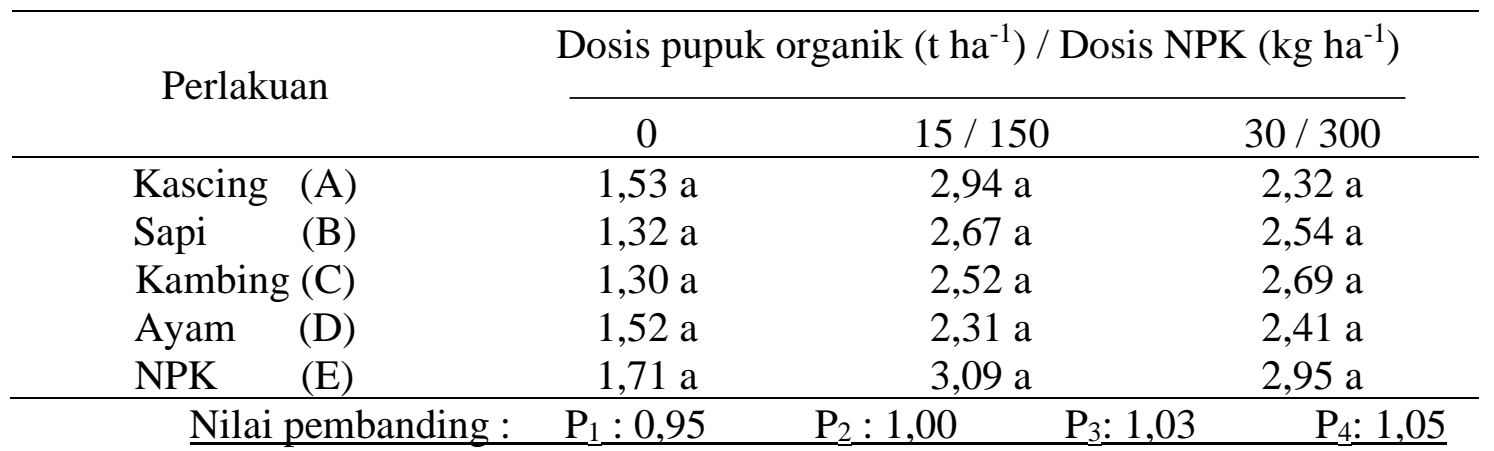

Keterangan : angka-angka yang diikuti oleh huruf yang sama pada kolom yang sama berarti berbeda tidak nyata berdasarkan pada uji Duncan $5 \%$

Hasil percobaan menunjukkan hijau. Hal yang diduga menyebabkan berbeda pengaruh pupuk organik dan anorganik tidak tidak nyata yaitu karena populasi mikroba memberikan perbedaan yang nyata terhadap dalam tanah tinggi dan $\mathrm{pH}$ netral, maka dapat pertumbuhan dan hasil tanaman sawi hijau disimpulkan bahwa mikroba yang terdapat di (Brassica rapa L.) dan nilai RAE. Analisis dalam tanah adalah mikroba yang statistik menunjukkan hasil tidak berbeda menguntungkan yang menyebabkan hasil nyata, namun secara data pupuk kascing yang penelitian menjadi berbeda tidak nyata. lebih tinggi dan efektif terhadap pertumbuhan Perlakuan pupuk organik dapat memperbaiki dan hasil serta nilai RAE pada tanaman sawi sifat kimia tanah dan ketersediaan N, P dalam 
tanah dan meningkatkan populasi mikroba dan total jamur dalam tanah. Populasi mikroba yang meningkat menyebabkan peningkatan mineralisasi bahan organik tanah dan ketersediaan hara bagi tanaman (Arancon, et al 2006). Kandungan unsur hara yang ada dalam tanah tergolong baik yaitu $\mathrm{C}$ organik 2,4\% (sedang), $\mathrm{pH}$ netral $(6,65)$, populasi mikroorganisme tinggi $\left(51 \times 10^{6}\right)$ dan dinilai telah cukup untuk pertumbuhan tanaman, sehingga dengan adanya penambahan unsur hara dari pupuk organik membuat perlakuan tidak memberikan kontribusi terhadap pertumbuhan tanaman.

Ditinjau dari parameter tinggi tanaman antara perlakuan tanpa pupuk dengan perlakuan pada pupuk organik kascing, pupuk kandang sapi, pupuk kandang kambing, pupuk kandang ayam dan NPK mutiara, menunjukkan hasil yang tidak berbeda nyata. Hal ini menunjukkan bahwa kandungan unsur hara pada masing masing pupuk sangat mempengaruhi pertumbuhan tanaman sawi hijau dan mengindikasikan bahwa pertumbuhan setiap tanaman dengan perlakuan yang berbeda menghasilkan tinggi bibit yang sama dan data hasil analisis tanah akhir dapat dilihat pada tabel 11. Ditinjau dari parameter jumlah daun antara perlakuan tanpa pupuk dengan perlakuan pada pupuk organik kascing, pupuk kandang sapi, pupuk kandang ayam, pupuk kandang kambing dan NPK mutiara, menunjukkan hasil yang tidak berbeda nyata. Pada parameter panjang daun menunjukkan hasil yang tidak berbeda nyata. Perlakuan pupuk organik kascing 15 ton/ha merupakan dosis pupuk organik yang paling baik untuk pertumbuhan lebar daun. Hal ini disebabkan karena kandungan unsur $\mathrm{N}$ yang terdapat dalam kompos dapat membantu dalam pertumbuhan lebar daun pada tanaman sawi hijau. Menurut Lakitan (2007), menyatakan bahwa senyawa esensial bagi tumbuhan yang terkandung dalam klorofil merupakan komponen penyusun nitrogen. Perlakuan pupuk organik memberikan nilai pengaruh yang tidak berbeda nyata pada berat segar tanaman. Prasetya, et al., (2009) menyatakan bahwa bobot segar tanaman dipengaruhi oleh tinggi tanaman dan luas daun, semakin tinggi tanaman dan semakin besar luas daunnya maka bobot segar tanaman akan semakin tinggi. Berat kering tanaman dipengaruhi oleh perkembangan daun dan intensitas matahari, tanaman yang memiliki daun yang lebih luas dapat menyerap sinar matahari dengan efektif sehingga dapat menghasilkan fotosintat lebih banyak karena dapat melakukan fotosintesis dengan baik. Perlakuan pupuk organik memberikan nilai pengaruh yang tidak berbeda nyata terhadap 
ARJUNA YOHANNES SIMANULLANG. et al. Pengaruh Pupuk Organik dan Anorganik...

berat segar akar. Hal ini karena caisim berbeda nyata terhadap berat kering akar. merupakan tanaman sukulen sehingga Faktor yang mempengaruhi pola penyebaran kandungan air pada jaringan tanaman yang akar antara lain adalah suhu tanah, aerasi, cukup tinggi. Perlakuan pupuk organik ketersediaan air, dan ketersediaan unsur hara. memberikan nilai pengaruh yang tidak

Tabel 11. Pengukuran Sifat Kimia dan Biologi Tanah setelah panen

\begin{tabular}{cccccc}
\hline & \multicolumn{5}{c}{ Variabel Pengamatan } \\
\cline { 2 - 6 } Perlakuan & $\begin{array}{c}\text { Total } \\
\text { Mikroba } \\
\left(\mathrm{cfu} \mathrm{g}^{-1}\right)\end{array}$ & $\begin{array}{c}\mathrm{N} \\
(\%)\end{array}$ & $\begin{array}{c}\mathrm{P} \\
(\mathrm{ppm})\end{array}$ & $\begin{array}{c}\text { Respirasi } \\
\text { Tanah } \\
\left(\mathrm{mg} \mathrm{CO}_{2} \mathrm{C}^{-}\right)\end{array}$ & $\begin{array}{r}\text { Kadar Air } \\
(\%)\end{array}$ \\
\hline $\mathrm{A}_{0}$ & $1,0 \times 10^{6}$ & 0,25 & 104,51 & 6,34 & 8,92 \\
$\mathrm{~A}_{1}$ & $1,4 \times 10^{6}$ & 0,23 & 117,83 & 9,02 & 9,74 \\
$\mathrm{~A}_{2}$ & $1,4 \times 10^{6}$ & 0,24 & 120,98 & 9,22 & 9,62 \\
$\mathrm{~B}_{0}$ & $1,1 \times 10^{6}$ & 0,25 & 145,64 & 8,57 & 8,43 \\
$\mathrm{~B}_{1}$ & $0,7 \times 10^{6}$ & 0,17 & 161,33 & 8,40 & 7,85 \\
$\mathrm{~B}_{2}$ & $0,9 \times 10^{6}$ & 0,17 & 111,05 & 9,17 & 8,11 \\
$\mathrm{C}_{0}$ & $0,6 \times 10^{6}$ & 0,20 & 145,29 & 9,10 & 8,29 \\
$\mathrm{C}_{1}$ & $1,2 \times 10^{6}$ & 0,19 & 119,12 & 8,91 & 9,93 \\
$\mathrm{C}_{2}$ & $1,1 \times 10^{6}$ & 0,25 & 145,45 & 9,20 & 9,51 \\
$\mathrm{D}_{0}$ & $1,0 \times 10^{6}$ & 0,25 & 156,21 & 9,20 & 9,84 \\
$\mathrm{D}_{1}$ & $1,0 \times 10^{6}$ & 0,26 & 156,11 & 9,14 & 8,06 \\
$\mathrm{D}_{2}$ & $1,3 \times 10^{6}$ & 0,26 & 155,20 & 9,20 & 7,71 \\
$\mathrm{E}_{0}$ & $0,9 \times 10^{6}$ & 0,23 & 185,01 & 9,08 & 8,26 \\
$\mathrm{E}_{1}$ & $0,3 \times 10^{6}$ & 0,23 & 207,92 & 7,91 & 7,01 \\
$\mathrm{E}_{2}$ & $0,1 \times 10^{6}$ & 0,23 & 200,66 & 7,42 & 7,24 \\
\hline Keterangan : A (Pupuk kascing), B (Pupuk kandang sapi), C (Pupuk kandang kambing), D \\
\multicolumn{7}{c}{ (Pupuk kandang ayam), 0 ton/ha, 1 (15 ton/ha), 2 (30 ton/ha), dan E (NPK } \\
\end{tabular}


Tabel 12 Nilai Relatif Agronomic Efectivites(RAE)

\begin{tabular}{ccc}
\hline No & Perlakuan & Nilai RAE (\%) \\
\hline 1 & $\mathrm{~A}_{0}$ & - \\
2 & $\mathrm{~A}_{1}$ & 103 \\
3 & $\mathrm{~A}_{2}$ & 76 \\
4 & $\mathrm{~B}_{0}$ & - \\
5 & $\mathrm{~B}_{1}$ & 50 \\
6 & $\mathrm{~B}_{2}$ & 69 \\
7 & $\mathrm{C}_{0}$ & - \\
8 & $\mathrm{C}_{1}$ & 71 \\
9 & $\mathrm{C}_{2}$ & 75 \\
10 & $\mathrm{D}_{0}$ & - \\
11 & $\mathrm{D}_{1}$ & 83 \\
12 & $\mathrm{D}_{2}$ & 67 \\
13 & $\mathrm{E}_{0}$ & - \\
14 & $\mathrm{E}_{1}$ & 100 \\
15 & $\mathrm{E}_{2}$ & 100 \\
\hline
\end{tabular}

Keterangan : A (Pupuk kascing), B (Pupuk kandang sapi), C (Pupuk kandang kambing), D (Pupuk kandang ayam), 0 (kontrol), 1 (15 ton/ha), 2 (30 ton/ha), dan E (NPK Mutiara) 0 (kontrol) 1, (150 kg/ha), 2 (300 kg/ha).

RAE dihitung menurut Machay et al. (1984) adalah sebagai berikut:

BST pada pupuk yang di uji - BST pada kontrol

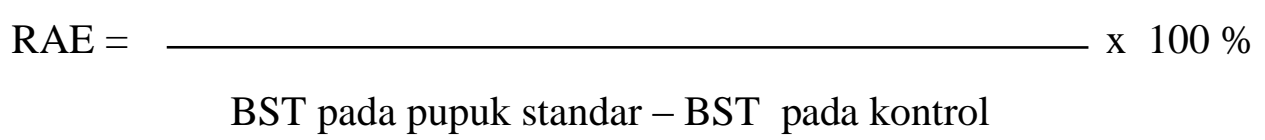

Hasil analisa laboratorium tanah \% yang menyatakan bahwa pupuk kascing penelitian yaitu total populasi mikroba dengan dosis 15 ton/ha mempunyai potensial menunjukkan nilai populasi yang berbeda untuk meningkatkan produktivitas pada pada setiap perlakuan tanah. Sumber nitrogen tanaman sawi hijau sehingga mampu menjadi sangat mempengaruhi bertambah nya pengganti pupuk kimia, sedangkan pada populasi mikroba. Budi (2005) menyatakan perlakuan lain yaitu (B1), (B2), (C1), (D2) bahwa mikroorganisme akan mampu tumbuh nilai RAE nya $\leq 100 \%$ yang menunjukkan dengan cepat dengan adanya unsur nitrogen bahwa penggunaan pupuk kurang efektif dan beberapa membutuhkan unsur nitrogen untuk meningkatkan produktivitas tanaman. yang absolut. Nilai RAE tertinggi > $100 \%$ adalah pada perlakuan (A1) yaitu sebesar 103 
ARJUNA YOHANNES SIMANULLANG. et al. Pengaruh Pupuk Organik dan Anorganik...

\section{SIMPULAN}

1. Perlakuan pengaruh pupuk organik dan anorganik tidak memberikan pengaruhyang nyata terhadap pertumbuhan dan hasil tanaman sawi hijau.

2. Perlakuan pengaruh pupuk organik dan anorganik tidak memberikan perbedaan yang nyata terhadap nilai Relative Agronomic Effectiveness (RAE), namun pupuk kascing menunjukkan nilai RAE lebih tinggi dan efektif dibandingkan dengan pupuk organik lainnya yang diuji.

3. Kadar $\mathrm{N}$ total tanah pada pupuk organik kascing yaitu 0,23 \% sama dengan perlakuan pupuk NPK Mutiara sebesar $0,23 \%$. Analisis kandungan total populasi mikroba menunjukkan bahwa perlakuan pupuk organik kascing 15 ton/ha dan 30 ton/ha sama yaitu 1,4 x $10^{6}$ cfu/g sedangkan pupuk NPK Mutiara sebesar $0,3 \times 10^{6} \mathrm{cfu} / \mathrm{g}$.

\section{DAFTAR PUSTAKA}

Adriani dan Syahfari, H. 2017. Pengaruh Waktu Pemberian dan Dosis Pupuk Kandang Sapi Terhadap Pertumbuhan dan Hasil Tanaman Sawi (Brassica juncea L.). Samarinda. Skripsi Universitas 17 Agustus 1945. Arancon, N. Q., C. A. Edwards, P. Bierman. 2006. Influences of vermicompots on field strawberries: Part 2. Effect on soil microbiological and chemical properties Bioresource Technology 97 (2006) 831-840.

Artha, G. M., Sulistyawati., Pratiwi, S. H. 2018. Efektivitas Pemberian Pupuk Kascing Terhadap Pertumbuhan dan Hasil Sawi. Pasuruan. Universitas Merdeka Pasuruan.

Budi Kun, 2005. Studi Pembuatan Pupuk Organik Cair dari Fermentasi Urine Sapi dengan Variasi Lokasi Peternakan yang Berbeda. Jurnal Program Studi Teknik Lingkungan. Fakultas Teknik, Universitas Diponegoro. Semarang.

Cindra, D. S., Pomalingo, N., \& Nurmi. 2013. Pertumbuhan dan Produksi Tanaman Sawi dengan Pemberian Dosis Pupuk Organik Kotoran Ayam. Universitas Gorontalo. Gorontalo.

Lakitan, B. 2007. Dasar-Dasar Fisiologi Tumbuhan. PT Raja Grafindo Persada, Jakarta. Pp 203.

Prabowo, R. 2008. Kajian Biopestisida dan Pupuk Hayati Dalam Mendukung Pengelolaan Tanaman Tomat Secara Terpadu. Jurnal

Mediagro.Vol.4.NO.1.2008:HAL :81-88.

Prasetya, B., S. Kurniawan, dan M. Febrianingsih. 2009. (Brassica Juncea L.) pada Entisol. Jurnal Agritek 17 (5): 1022-1029.

Suparhun, S. Anshar, M. Tambing, Y. 2015. Pengaruh pupuk organik dan poc dari kotoran kambing terhadap pertumbuhan tanaman sawi (Brassica juncea L.). Bogor. IPB. 